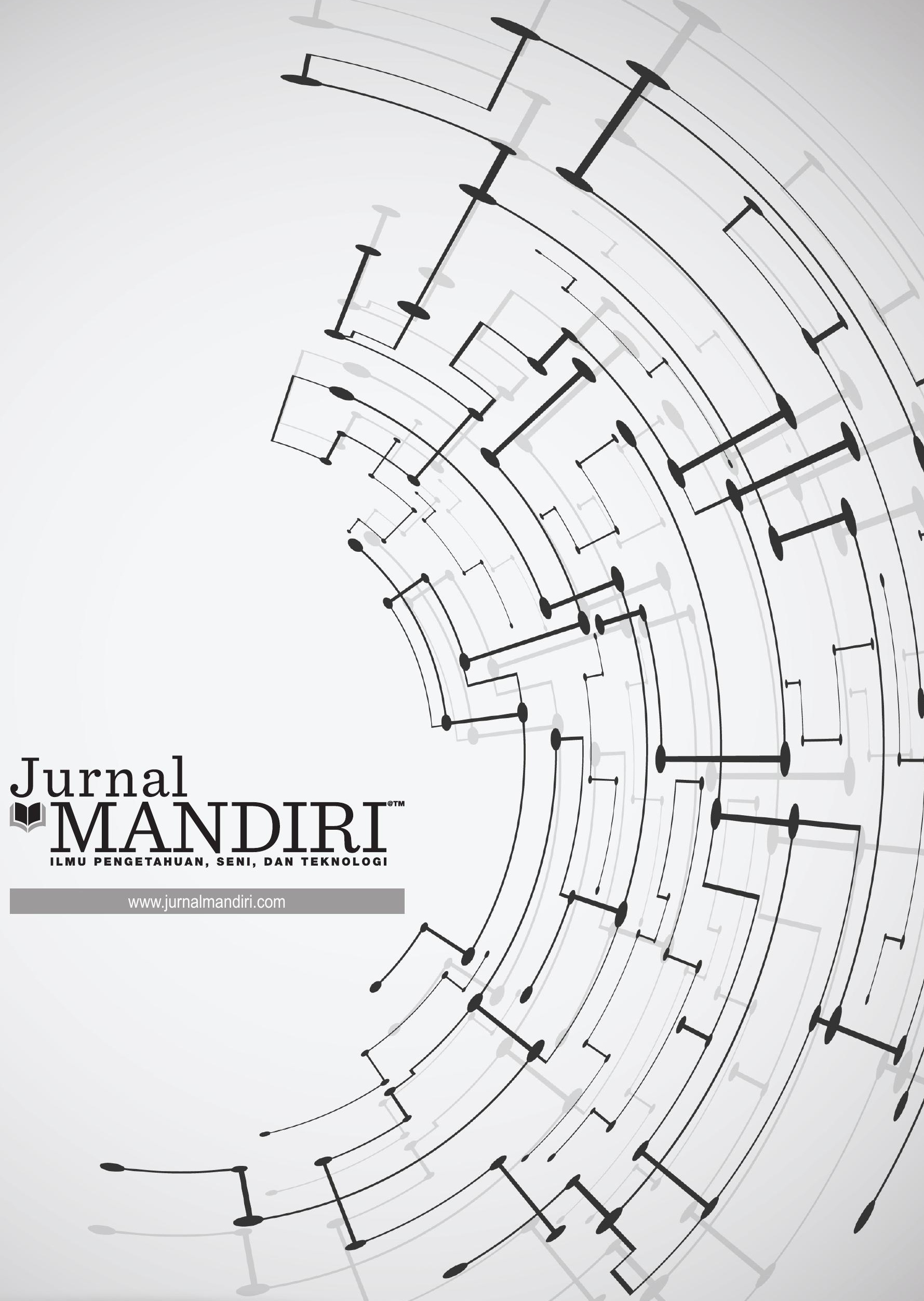


ISSN : 2580-3220, E-ISSN : 2580-4588

J. Mandiri., Vol. 3, No. 2, Desember 2019 (294 - 306)

C2018 Lembaga Kajian Demokrasi

dan Pemberdayaan Masyarakat (LKD-PM)

DOI : https://doi.org/10.33753/mandiri.v3i2.91

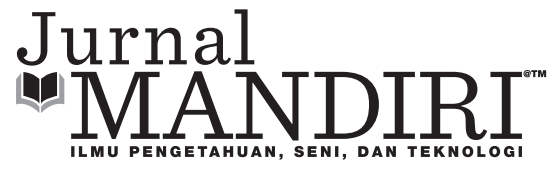

\title{
Analisis Revitalisasi Pasar Tradisional Untuk Meningkatkan Pendapatan Daerah Kota Tangerang Selatan, Provinsi Banten
}

\author{
Syamruddin \\ Fakultas Ekonomi, Universitas Pamulang \\ dosen01343@unpam.ac.id \\ Ahmad Yani Nasution \\ Fakultas Ekonomi, Universitas Pamulang \\ ahmed_nasty@yahoo.co.id
}

\begin{abstract}
Abstrak
Penelitian ini mendeskripsikan tentang kondisi pasar-pasar tradisional di Kota Tangerang Selatan. Penelitian bertujuan untuk mengetahui hubungan antara revitalisasi pasar tradisional dengan peningkatan pendapatan daerah Kota Tangerang Selatan. Selain itu untuk melihat perbandingan antara pengelolaan pasar tradisional dengan pasar modern. Adapun metode penelitian yang digunakan adalah metode sebab-akibat. Metode analisis data yang digunakan adalah analisis komparatif dan kompetitif dari hubungan sebab akibat antara revitalisasi pasar dengan pendapatan daerah. Disebabkan penelitian ini merupakan penelitian kualitatif, maka selama penelitian dimungkinkan adanya perkembangan penelitian atau hasil dari rumusan masalah yang telah ditetapkan. Hasil penelitian menunjukkan bahwa ada hubungan antara revitalisasi pasar tradisional dengan peningkatan pendapatan daerah. Sehingga perlu segera dilakukan revitaliasasi terhadap pasar tradisional yang ada di Kota Taangerang selatan. Sebab potensi pendapatan daerah yang akan diperoleh setelah revitalisasi akan sangat banyak dan besar sekali. Adapun potensi tersebut antara lain pengelolaan parkir, pajak restoran, reklame, izin usaha pertokoan, pajak bumi dan bangunan, penyewaan perkantoran, penyewaan tempat untuk pameran, penyewaan toko seperti di mall, rumah dan toko (ruko), dan pengelolaan sampah. Dengan adanya revitalisasi pasar tradisional maka diharapkan akan meningkatkan pendapatan daerah. Sedangkan implikasi dari hasil penelitian ini adalah dikeluarkannya kebijakan atau regulasi oleh Pemerintah Kota Tangerang Selatan tentang revitalisasi pasar tradisional.
\end{abstract}

Kata Kunci : Revitalisasi, Pasar Tradisional, Retribusi, Pendapatan Daerah

\begin{abstract}
This study describes the condition of traditional markets in South Tangerang City. The study aims to determine the relationship between traditional market revitalization with increased income in the area of South Tangerang City. In addition to see the comparison between traditional market management with modern markets. The research method used is a causal method. The data analysis method used is a comparative and competitive analysis of the causal relationship between market revitalization and regional income. Because this research is a qualitative study, so long as the research is possible the development of research or the results of the formulation of the problem that has been determined. The results showed that there was a relationship between traditional market revitalization and an increase in regional income. So that it is necessary to immediately revitalize the traditional market in southern Taangerang City. Because the potential of regional income that will be obtained after revitalization will be very large and enormous. The potential includes parking management, restaurant tax, billboards, shop business permits, land and building tax, office rental, exhibition space rental, shop rental
\end{abstract}


such as in malls, houses and shops (shop houses), and waste management. With the revitalization of traditional markets, it is expected to increase regional income. While the implications of the results of this study are the issuance of policies or regulations by the South Tangerang City Government regarding the revitalization of traditional markets.

Keywords : Revitalization, Traditional Market, Retribution, Regional Revenue

\section{PENDAHULUAN}

Penelitian ini memfokuskan pada kaitan antara revitalisasi pasar tradisional dalam upaya untuk meningkatkan pendapatan daerah Kota Tangerang Selatan. Untuk lebih memudahkan penelitian, maka subjek yang diteliti adalah para pengelola pasar tradisional dan Dinas Perindustrian dan Perdagangan serta Dinas-Dinas yang terkait dalam pengelolaan pasar tradisional di Kota Tangerang Selatan. Lokasi penelitian meliputi Pasar Serpong, Pasar Jengkol, Pasar Bintaro Sektor 2, Pasar Jombang, Pasar Kita Pamulang, Pasar Ciputat, dan Pasar Ciputat Permai (Cimanggis).

Kota Tangerang Selatan merupakan wilayah pecahan atau pemekaran dari Kabupaten Tangerang. Kota yang merupakan daerah urban dari Kota Metropolitan Jakarta ini didirikan berdasarkan UU. No. 51/2008 tentang Pembentukan Kota Tangerang Selatan di Provinsi Banten tertanggal 26 November 2008.

Kota Tangerang Selatan memiliki tujuh wilayah kecamatan dan 54 kelurahan. Kota Tangerang Selatan merupakan wilayah suburban yang berada di pinggir DKI Jakarta. Batas wilayah Kota Tangerang Selatan adalah: (1) sebelah utara ber-

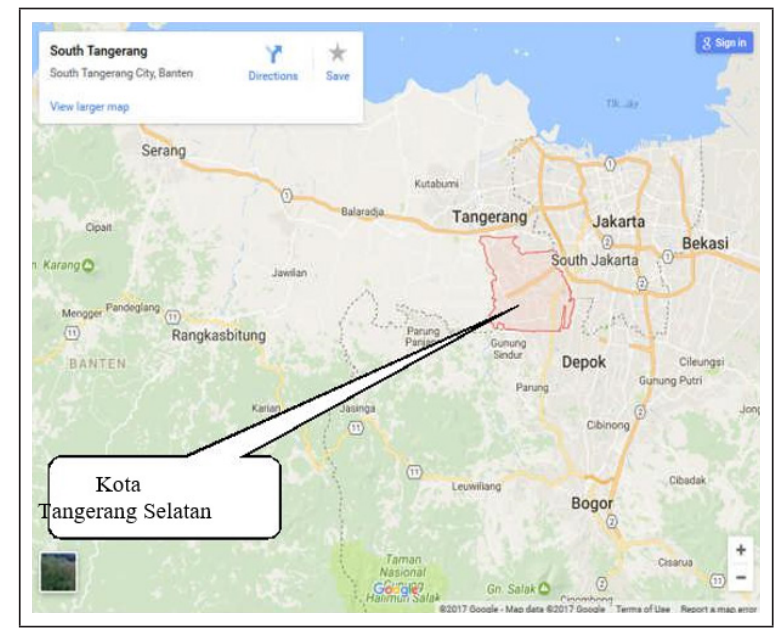

Gambar 1. Peta Kota Tangerang Selatan batasan dengan Provinsi DKI Jakarta dan Kota Tangerang; (2) sebelah timur berbatasan dengan Provinsi DKI Jakarta dan Kota Depok; (3) sebelah selatan berbatasan dengan Kabupaten Bogor dan Kota Depok; dan (4) sebelah barat berbatasan dengan Kabupaten Tangerang.

Martini et al (2016), mengatakan, perlunya revitalisasi pasar dengan menjaga keamanan pasar agar dapat kondusif. Saran yang diberikan yaitu dengan strategi pertumbuhan, baik dengan cara integrasi vertikal, penetrasi pasar, dan pengembangan produk.

Secara demografi, geografi, dan ekonomi, Kota Tangerang Selatan memiliki potensi yang sangat besar bagi perkembangan pasar tradisional. Apalagi, kalau dilihat dari postur Anggaran Pendapatan dan Belanja Daerah (APBD) Kota Tangerang Selatan dari tahun ke tahun yang terus mengalami peningkatkan. Namun, kontribusi dari retribusi pasar tradisional masih sangat kecil. Oleh karena itu, maka cara yang tepat untuk meningkatkan pendapatan pasar selain retribusi adalah dengan melakukan revitalisasi.

Revitalisasi adalah suatu proses atau cara dan perbuatan untuk menghidupkan kembali suatuhal yang sebelumnya terberdaya sehingga revitalisasi berarti menjadikan sesuatu atau perbuatan untuk menjadi vital, sedangkan kata vital mempunyai arti sangat penting atau sangat diperlukan sekali untuk kehidupan dan sebagainya. Atau dengan kata lain, revitalisasi adalah upaya untuk memvitalkan kembali suatu kawasan atau bagian kota yang dulunya pernah vital/hidup, akan tetapi kemudian mengalami kemunduran/ degradasi.

Ahmad Heri Firdaus, peneliti Institute for Development of Economics and Finance (INDEF) (2019), mengemukakan, revitalisasi pasar sangat bagus untuk menarik kembali konsumen-konsumen agar mau berbelanja ke pasar dan juga meningkatkan akses masyarakat terhadap kebu- 
tuhan utama. Dengan semakin ramainya pasar tradisional, maka kesempatan usaha mikro, kecil, dan menengah (UMKM) untuk semakin berkembang jadi luas. Hal ini mengingat badan pengelola pasar tradisional kerap memiliki pola kemitraan dengan UMKM. Sehingga keterlibatan pemerintah di sini penting, terutama akan bisa memicu perekonomian di wilayah yang dimotori UMKM.

Sementara itu Sukaatmadja (2014), dengan menggunakan analisis SWOT, saran pengembangan yang dapat dilakukan adalah dengan mereduksi kelemahan yang terdapat dalam pasar tradisional, yaitu: penyediaan sarana parkir, pembaharuan metode transaksi, penertiban lapak zonasi, tata kelola limbah/sampah pasar, penyediaan fasilitas umum, dan pelayanan konsumen.

Selama ini pengelolaan pasar-pasar tradisional di berbagai daerah di Indonesia kurang maksimal. Termasuk pengelolaan pasar-pasar tradisional yang ada di Kota Tangerang Selatan. Kendati rencana pengelolaannya akan diserahkan ke BUMD Tangerang Selatan, namun pasar-pasar tersebut masih dibiarkan berkembang begitu saja sehingga optimalisasi pendapatan yang diharapkan dari aset tersebut tidak bisa dilakukan maksimal. Pengelolaannya pun baru sebatas dalam bentuk manajemen yang sederhana. Kondisi pasar yang tidak nyaman membuat masyarakat semakin lama semakin meninggalkan pasar tradisional.

Berikut kondisi sebagian pasar tradisional yang ada di Kota Tangerang Selatan sebagaimana terlihat pada gambar di bawah ini :

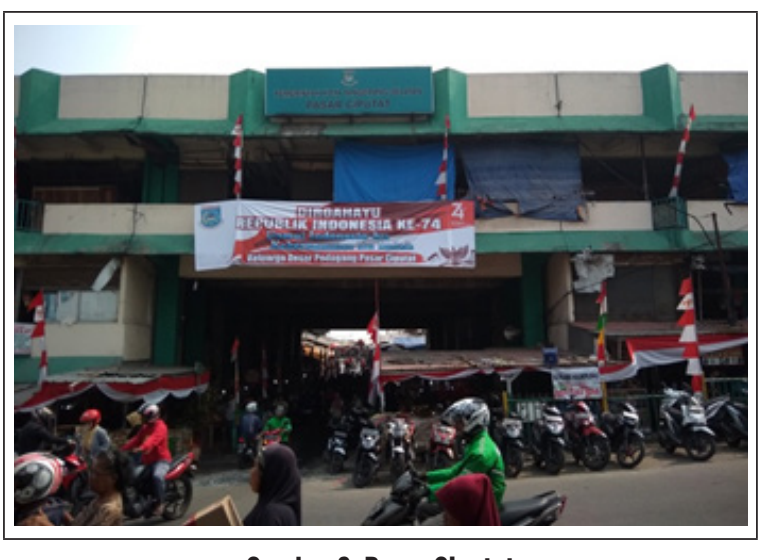

Gambar 2. Pasar Ciputat

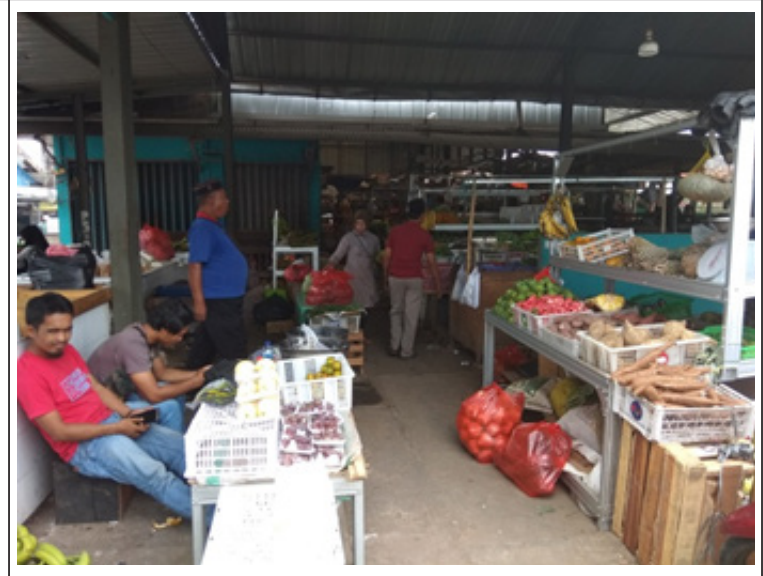

Gambar 3. Pasar Jengkol

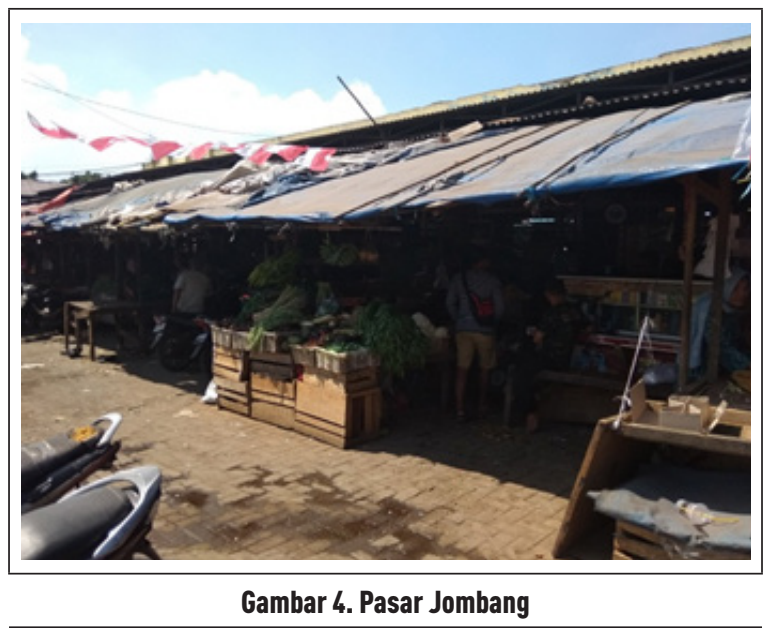

Dari 21 indikator persaingan bauran pemasaran, sebanyak $76 \%$ dikuasasi oleh pasar modern (Purwanto, 2012). Selain itu, studi yang dilakukan Sadino dan Syahbana (2014) misalnya menyimpulkan bahwa keunggulan pasar modern dibandingkan pasar tradisional terletak pada atribut keragaman, kualitas barang, kenyamanan, promosi serta lokasi. Membaca situasi demikian, masalah pasar tradisional sebenarnya memang bersumber dari tubuh internalnya sendiri (Suryadarma, 2007).

Pada penelitian sebelumnya, Pitri Yandri (2018) dalam tulisannya berjudul: "Determinasi Tarif Retribusi Pasar Tradisional Dengan Pendekatan Willingness To Pay dan Perbandingan Harga Pasar", menunjukkan bahwa pendapatan retribusi dari beberapa pasar tradisional di Kota Tangerang Selatan masih sangat kecil. Hal itu sebagaimana terlihat pada gambar di bawah ini : 


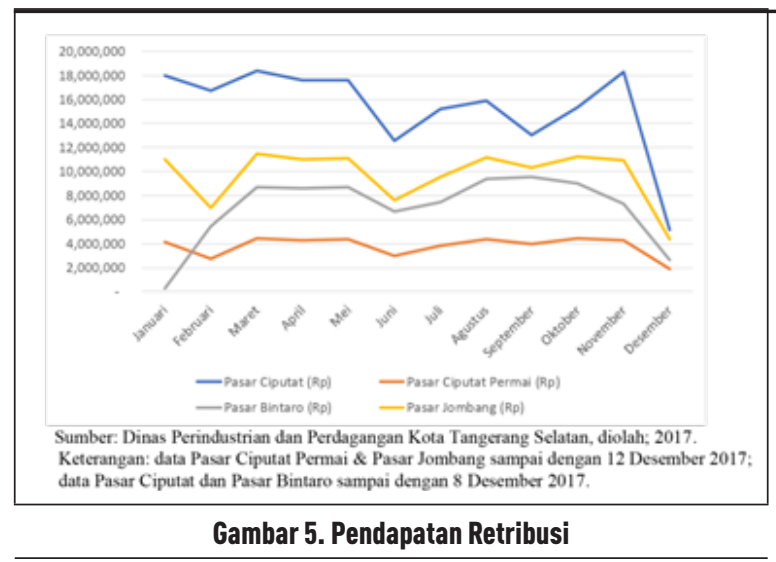

Dalam penelitian ini, penulis menemukan adanya hubungan antara revitalisasi pasar tradisional dengan pendapatan daerah. Apabila dilakukan revitalisasi, maka pendapatan tidak hanya dari sisi retribusi pasar, namun juga akan berasal dari pos-pos lain seperti pengelolaan perparkiran, pajak restoran, dan reklame. Sebagaimana halnya pengelolaan pasar yang telah dilakukan oleh dua pasar modern yang ada di Kota Tangerang Selatan yaitu Pasar Modern BSD, Serpong dan Pasar Modern Bintaro.

Adapun tujuan penulisan artikel ini adalah untuk memberikan gambaran sejauh mana pengelolaan pasar tradisional, mengapa pasar tradisional perlu direvitalisasi, dan bagaimana pentingnya dilakukan revitalisasi. Kemudian sebagai bahan masukan bagi Pemerintah Kota Tangerang Selatan di mana dengan adanya revitalisasi maka pengelolaan pasar akan berdampak pada peningkatan pendapatan daerah, tidak hanya melalui retribusi pasar.

\section{METODE}

Metode yang digunakan pada penelitian adalah dengan cara pengumpulan data sekunder, melakukan observasi, dan survei. Selanjutnya dilakukan wawancara dan pengisian kuesioner kepada para responden untuk mengumpukan data primer. Kemudian dilanjutkan wawancara dengan pihak-pihak yang terkait dalam upaya revitalisasi pasar di Kota Tangerang Selatan.

Selain itu data yang digunakan dalam penelitian ini merupakan data yang berasal dari data sekunder sesuai yang dibutuhkan. Data sekunder penelitian ini berasal dari Dinas Perindustrian dan Perdagangan Kota Tangerang Selatan sebagai wilayah analisis.

Untuk medapatkan data sekunder, penulis juga melakukan penelahaan literatur seperti halnya buku-buku kuliah dan data yang diperoleh dalam bentuk jadi, yang sudah diolah oleh pihak lain. Bahan-bahan tersebut biasaya dalam bentuk publikasi serta hal-hal yang berhubungan dengan masalah yang berkaitan dengan penelitian ini.

Metode analisis data yang digunakan oleh penulis adalah dengan menggunakan analisis komparatif dan kompetitif dari hubungan sebab akibat revitalisasi pasar dengan pendapatan daerah.

Kemudian data dianalisis dengan pertanyaan penelitian yang relevan dengan revitalisasi pasar di Kota Tangerang selatan. Melakukan pengamatan pendahuluan di mana dalam proses tersebut dilakukan penggalian data melalui studi pustaka untuk menyusun pedoman wawancara yang akan digunakan sebagai salah satu alat penggali data dari nara sumber yang berwenang. Selanjutnya pengujian keabsahan data dilakukan melalui pendekatan penelitian kualitatif.

\section{HASIL dan PEMBAHASAN}

Pasar adalah salah satu dari berbagai sistem, institusi, prosedur, hubungan sosial, dan infrastruktur di mana usaha menjual barang, jasa, dan tenaga kerja untuk orang-orang dengan imbalan uang. Barang dan jasa yang dijual menggunakan alat pembayaran yang sah seperti uang. Kegiatan ini merupakan bagian dari perekonomian. Ini adalah pengaturan yang memungkinkan pembeli dan penjual untuk item pertukaran. Persaingan sangat penting dalam pasar, dan memisahkan pasar dari perdagangan.

Sedangkan pasar tradisional merupakan tempat bertemunya penjual dan pembeli serta ditandai dengan adanya transaksi penjual pembeli secara langsung dan biasanya ada proses tawar-menawar, bangunan biasanya terdiri dari kios-kios atau gerai, los dan dasaran terbuka yang dibuka oleh penjual maupun suatu pengelola pasar.

Selanjutnya program revitalisasi pasar tradi- 
sional atau pasar rakyat merupakan pelaksanaan dari Undang-undang nomor 7 tahun 2014 tentang Perdagangan, pasal 13 ayat (1), (2), dan (3) yang mengamanatkan bahwa Pemerintah bekerja sama dengan Pemerintah Daerah melakukan pembangunan, pemberdayaan, dan peningkatan kualitas pengelolaan pasar rakyat guna peningkatkan daya saing dalam bentuk pembangunan dan/atau revitalisasi pasar rakyat; implementasi manajemen pengelolaan yang profesional; fasilitasi akses penyediaan barang dengan mutu yang baik dan harga yang bersaing; dan fasilitasi akses pembiayaan kepada pedagang pasar di pasar rakyat.

Maksud dan tujuan revitalisasi atau pembangunan pasar rakyat adalah : (1) mendorong agar pasar rakyat lebih modern dan mampu bersaing dengan pusat perbelanjaan dan toko modern, sehingga dapat meningkatkan omset pedagang pasar rakyat. (2) Meningkatkan pelayanan dan akses yang lebih baik kepada masyarakat konsumen, sekaligus menjadikan pasar rakyat sebagai penggerak perekonomian daerah. (3) Mewujudkan pasar rakyat yang bermanajemen modern, lebih bersih, sehat, aman, segar, dan nyaman, sehingga dapat menjadi tujuan tetap belanja konsumen serta referensi dalam

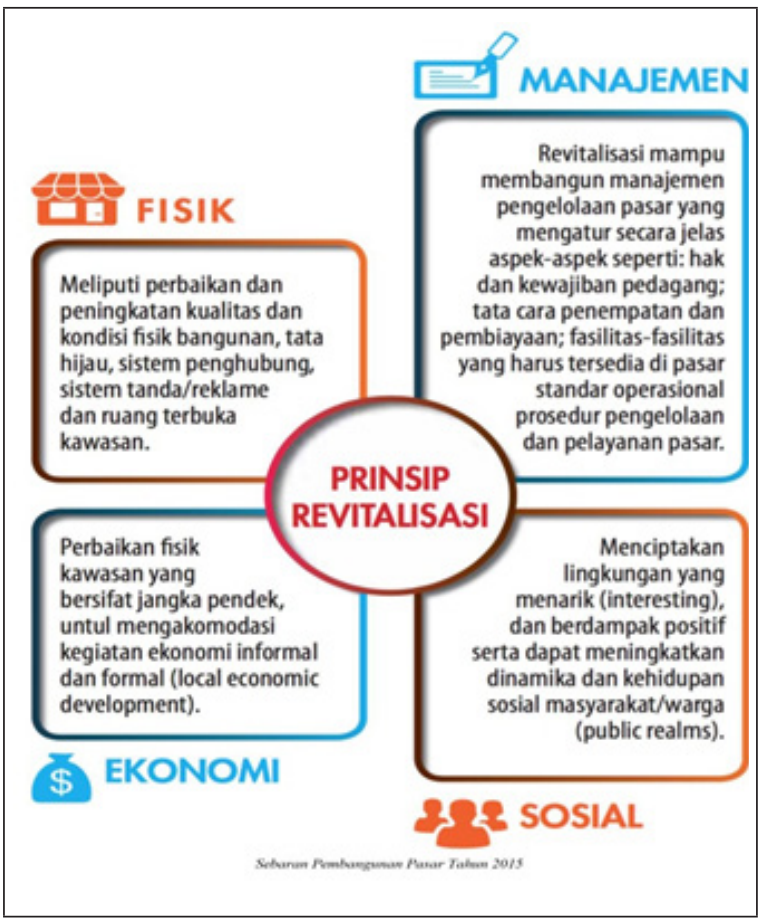

Gambar 6. Konsep \& Prinsip-Prinsip Revitalisasi pembangunan pasar-pasar lainnya.

Konsep dan prinsip revitalisasi pasar rakyat yang merupakan program revitalisasi pasar rakyat Kemendag RI bukan hanya menyentuh perbaikan dari sisi perbaikan fisik saja, melainkan juga dari sisi ekonomi, sosial budaya, dan manajemen. Adapun prinsip-prinsip revitalisasi yang dimaksudkan sebagaimana terlihat pada gambar di atas ini.

Apabila dilihat dari perspektif desentralisasi, silang-sengkarut masalah yang dihadapi pasar tradisional berdampak nyata terhadap makroekonomi daerah. Gejala rendahnya penerimaan retribusi pasar terhadap pendapatan asli daerah (PAD) merupakan salah satu bukti nyata bahwa pasar tradisional belum mampu menjadi penyumbang signifikan bagi PAD. Hasil studi tentang hal ini dapat terbaca dalam artikel yang ditulis Megawati dan Soejoto (2016); Marselina (2013); dan Handoko (2012).

Atas dasar masalah tersebut, sejumlah akademisi kemudian menyarankan perlunya menyusun strategi dan mengambil kebijakan yang lebih punya dampak pasti terhadap perbaikan kondisi pasar tradisional. Dalam kaitan itu, Martini et al (2016), Sukaatmadja (2014), dan Istiningtyas (2008) merekomendasikan beberapa kebijakan yang penting dilakukan dalam upaya menyelesaikan problem silang-sengkarut tersebut. Saran kebijakan revitalisasi terhadap pasar tradisional juga ditulis dalam artikel Pradipta dan Wirawan (2016), Prastyawan et al (2015), Holidin dan Andini (2014) dan Febrianty (2013).

Namun demikian, hasil studi kebijakan revitalisasi terhadap pasar tradisional masih sangat bervariasi. Di satu sisi, studi yang dilakukan Alfianita et al (2015) menyimpulkan bahwa kebijakan revitalisasi pasar berjalan dengan baik dan telah sesuai dengan prinsip tata kelola yang baik. Tetapi di sisi yang lain, studi yang dilakukan Asma (2016) misalnya menyatakan bahwa kebijakan revitalisasi dipandang belum efektif dalam upaya mendorong agar pasar tradisional menjadi lebih baik. Menurutnya, hal tersebut disebabkan oleh lemahnya penegakkan aturan.

Hasil 
Pengelolaan pasar yang ada di Kota Tangerang Selatan dikelompokkan kepada dua pengelola. Pertama, pasar tradisional yang dikelola oleh Pemerintah Kota Tangerang Selatan. Kedua, pasar modern yang dikelola oleh pihak swasta.

Pasar tradisional yang dikelola oleh Pemerintah Kota Tangerang Selatan yaitu Pasar Kita Pamulang, Pasar Ciputat Permai, Pasar Ciputat, Pasar Jombang, Pasar Bintaro Sektor 2, Pasar Jengkol, dan Pasar Serpong. Sedangkan secara manajeman dan teknis pengelolaannya dilaksanakan oleh Dinas Perindustrian dan Perdagangan Kota Tangerang Selatan, dalam hal ini Unit Pengelola Teknis Dinas (UPTD) Pengelolaan Pasar. Selanjutnya, untuk operasional di lapangan pengelolaannya diserahkan kepada para kepala pasar.

Sementara itu pasar modern yang antara lain terdiri dari Pasar BSD dan Pasar Bintaro, Pasar Segar Graha Raya Bintaro, dan Pasar Delapan Alam Sutera pengelolaannya sepenuhnya menjadi kewenangan pihak swasta. Pemerintah Kota Tangerang Selatan hanya mendapatkan pajak daerah sesuai dengan aturan yang berlaku.

Berdasarkan hasil observasi dan interview yang dilakukan di pasar modern yang ada di Kota Tangerang Selatan, yaitu Pasar Modern BSD dan Pasar Modern Bintaro, apabila dibandingkan dengan pasar tradisional maka akan terlihat sekali perbedaan sumber pendapatan pada kedua jenis pasar tersebut. Di pasar modern, sumber pendapatan yang bisa digali oleh pemerintah, selain retribusi pasar juga dari pengelolaan parkir, pemasangan reklame, pajak restoran, izin usaha pertokoan, dan lain-lain. Sedangkan di pasar tradisional sumber pendapatan yang bisa diperoleh oleh pemerintah hanya berasal dari retribusi pedagang.

Selanjutnya, untuk lebih mendapatkan data yang akurat terhadap rencana revitalisasi pasar tradisional di Kota Tangerang Selatan, selain melakukan wawancara dan pengambilan data ke Dinas Perindustrian dan Perdagangan dan pihak pengelola pasar tradisional, juga dilakukan sinkronisasi ke Badan Pendapatan Daerah (BAPENDA), Badan Perencanaan Pembangunan Daerah (BAPPEDA), Badan Pengelolaan Ke- uangan dan Aset Daerah (BPKAD), Bagian Perekonomian Sekretariat Daerah, Dinas Bangunan dan Penataan Ruang, Dinas Ketahanan Pangan, Pertanian, dan Perikanan serta Dinas Koperasi, Usaha Kecil, dan Menengah.

Sebab dalam revitalisasi pasar tradisional tidak hanya bisa mengandalkan satu dinas, namun perlu keterkaitan antara dinas-dinas yang berhubungan dengan pelaksanaan revitalisasi sesuai dengan tugas pokok dan fungsi (tupoksi) masing-masing dinas.

Adapun tupoksi dari Dinas Perindustrian dan Perdagangan yang menjadi instansi yang berwenang dalam pengelolaan pasar adalah sebagai berikut :

\section{Bidang Perdagangan}

1. Melakukan monitoring harga kebutuhan pokok secara berkala setiap minggu.

2. Melakukan Pendataan Pedagang Kaki Lima (PKL) di wilayah Tangerang Selatan.

3. Bimtek manajemen bagi usaha kecil.

4. Fasilitasi promosi bagi IKM ke luar negeri.

5. Pelatihan dan fasilitasi ekspor impor.

6. Pembuatan sarana dagang bagi PKL. Seksi Perdagangan Dalam Negeri

1. Penerbitan rekomendasi.

2. Ketersediaan barang.

3. Perdagangan kayu.

4. Revitalisasi perdagangan.

5. Pembinaan pelaku usaha.

\section{Seksi Promosi Usaha}

1. Menyelenggarakan pameran/promosi dagang dalam dan luar negeri.

2. Memfasilitasi pameran/promosi dagang dalam dan luar negeri.

3. Melaksanakan pembinaan/bimbingan teknis/ sosialisasi/seminar/kepada pelaku usaha dalam rangka pameran/promosi dagang dalam dan luar negeri.

\section{Bidang Perindustrian \\ Seksi IKM}

1. Menyusun rencana pembangunan dan pengembangan industri dan sentra industri kota.

2. Melaksanakan pembinaan/bimbingan teknis/ 
sosialisasi/seminar/kepada pelaku industri berbasis kompetensi.

3. Melakukan pemeriksaan lapangan dalam rangka penerbitan Izin Usaha Industri Kecil dan Izin Pengembangan Industri Kecil dan Menengah Usaha Industri Menengah, Izin Perluasan Usaha Industri, Izin Usaha Kawasan Industri, Izin Perluasan Kawasan Industri.

\section{Seksi Industri Kreatif}

Pelatihan terhadap industri kreatif diprioritaskan sehingga pada tahun 2013 sudah mencapai target dari rencana 50 IKM. Pencapaian kinerja tahun 2015 telah melebihi target yaitu sebanyak 780 IKM yng telah dilatih dan dibina atau sebesar $4.200 \%$.

\section{Seksi Data dan Informasi Industri}

1. Menyusun rencana pembangunan dan pengembangan industri dan sentra industri kota.
2. Melaksanakan pembinaan/bimbingan teknis/ sosialisasi/seminar/kepada pelaku berbasis kompetensi.

3. Melakukan pemeriksaan lapangan dalam rangka penerbitan Izin Usaha Industri Kecil dan Izin Pengembangan Industri Kecil dan Menengah, Izin Perluasan Usaha Industri, Izin Usaha Kawasan Industri, Izin Perluasan Kawasan Industri.

Pasar tradisional yang ada di Kota Tangerang Selatan baru mulai memberikan kontribusi kepada Pemerintah Kota Tangerang Selatan sejak tahun 2016. Bahkan ada dua pasar yang baru memberikan kontribusi retribusi pada tahun 2018 . Tentu, hal itu dapat dimaklumi karena penyerahan aset pasar dari Pemerintah Kabupaten Tangerang kepada Pemerintah Kota Tangerang Selatan dilaksanakan pada tahun 2015. Adapun data pasar tradisional yang ada di Kota Tangerang Selatan sebagai berikut :

Sementara itu penerimaan retribusi dari ma-

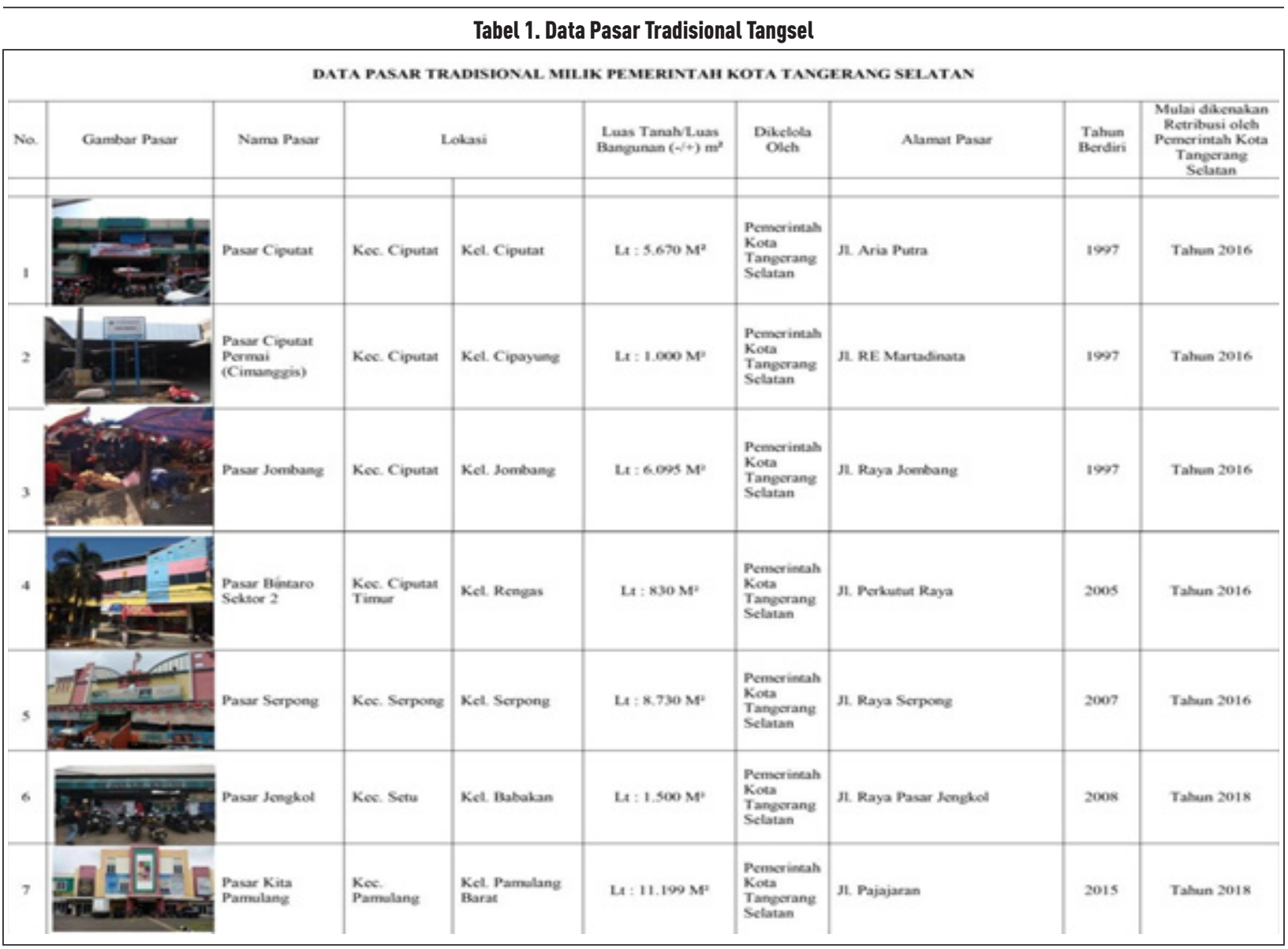


sing-masing pasar tradisional yang sudah masuk kas daerah sejak tahun 2016 masih sangat sedikit sekali. Jumlah tersebut apabila dibandingkan dengan pendapatan daerah yang terus meningkat dari tahun ke tahun sangat tidak signifikan.

Sumbangan retribusi dari pasar tradisional belum dapat dijadikan sebagai salah satu komponen bagi Pemerintah Kota Tangerang Selatan untuk meningkatkan pendapatan daerah. Sehingga perlu dilakukan terobosan dalam tata kelola pasar tradisional agar kelak menjadi salah satu sektor yang bisa dijadikan pos untuk penambahan pendapatan daerah. Hal itu sebagaimana terlihat pada tabel di bawah ini :

\begin{tabular}{|c|c|c|c|c|c|}
\hline \multicolumn{6}{|c|}{ Tabel 2. Penerimaan Setiap Pasar Tradisional } \\
\hline \multicolumn{6}{|c|}{ PENERIMAAN RETRIBISI PADA PASAR TRADISIONAL DI KOTA TANGERANG SELATAN } \\
\hline No. & Nama Pasar & Tahun 2016 & Tahun 2017 & Tahun 2018 & Jumlah \\
\hline & & & & & \\
\hline 1 & Pasar Jombang & $127,479.500$ & $134,311.500$ & 126.638 .500 & $388.429,500$ \\
\hline 2 & Pasar Ciputat & 183.028 .300 & 187.168 .200 & $240,827,500$ & 611.024 .000 \\
\hline 3 & Pasar Ciputat Permai (Cimangis) & 49.286 .000 & 49.264 .400 & $49.194,000$ & $147,744,400$ \\
\hline 4 & Pasat Bintaro Sektor 2 & $101,413,550$ & $105,443,000$ & 137.640 .850 & $344,497,400$ \\
\hline 5 & Pasar Semong & 708.944 .076 & $744,391,344$ & 744.391 .344 & 2.197 .726 .764 \\
\hline 6 & Pasar Kita Pamulang & & & $19.621,000$ & 19.621 .000 \\
\hline 7 & Pasar Jengkol & . & ${ }^{\circ}$ & $29.187,000$ & 29.187 .000 \\
\hline
\end{tabular}

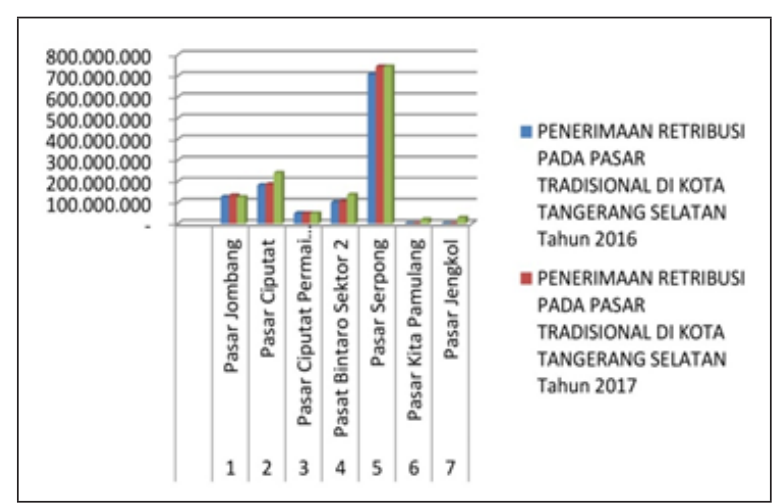

Sumber : Dinas Perindustrian dan Perdagangan Kota Tangerang Selatan, Tahun 2019

Sebagai gambaran, pendapatan daerah Kota Tangerang Selatan dari tahun ke tahun terus mengalami peningkataan. Sebagaimana terlihat dari tabel di bawah ini pada tahun 2014 pendapatan daerah sekitar Rp1,9 tirliun. Kemudian pada tahun 2019, pendapatan daerah meningkat tajam menjadi sekitar Rp3,2 triliun. Berikut tabel global APBD Kota Tangerang Selatan dari tahun 2014 sampai dengan tahun 2019.

Tabel 3. Ringkasan APBD Kota Tangerang Selatan 2014 s/d 2019

\begin{tabular}{|c|c|c|c|c|c|c|}
\hline \multicolumn{7}{|c|}{ APBD KOTA TANGERANG SELATAN DARI TAHUN 2014 S/D TAHUN 2019} \\
\hline Uraian & Tahun 2014 (rupiah) & Tahun 2015 (rupiah) & Tahun 2016 (rupiah) & Tahun 2017 (npiah) & Tahun 2018 (ruplah) & Tahun 2019 (rupiah) \\
\hline $\begin{array}{l}\text { ANGGARAN PENOAPATAN DAN } \\
\text { BELANLA DAERAH (APBO) }\end{array}$ & $2.493 .574 .062 .460,00$ & $2.843 .868 .046 .067,00$ & $3.304 .722 .367 .399,00$ & $3.443 .686 .072 .737,01$ & 3.569.146.581.087,09 & 3.764.388.943.235,00 \\
\hline Pendapatan & $1.948 .924 .605 .450,00$ & $2.321 .642 .450 .098,00$ & 2.580 .459 .404 .371 .00 & 2.775 .606 .072 .737 .01 & $3.075 .840 .873 .513,00$ & $3.287 .043 .919 .596,00$ \\
\hline Belania Doerah & 2.493 .574 .062 .450 .00 & 2.843888 .046 .067 .00 & $3.304 .722 .367 .399,00$ & $3.443 .696 .072 .737,01$ & $3.549 .146581 .087,09$ & 3.764 .388 .943 .235 .00 \\
\hline Surplus/Defasit & $(544,649,457,000,000)$ & (522.245.595.969.00) & {$[724.262 .963 .028,00]$} & {$[668.000 .000,000,00)$} & $(4773.305 .707 .574,09)$ & $(477.345 .023 .639,00)$ \\
\hline \multicolumn{7}{|l|}{ Pembiapann } \\
\hline Penerimanaan Pembiazaan Daerah & $566.429 .457,000,00$ & 522.245 .595 .969 .00 & $724.262 .963 .028,00$ & $668.000 .0000000,00$ & $495.305 .707 .574,09$ & $499.345 .023 .639,00$ \\
\hline Pengeluaran Pembizyan Daerzh & $21.760,000,000,00$ & of & 0 & 0 & $22.0000000,000,00$ & $22.000,000,000,00$ \\
\hline Pembiaran Netto & $544.649 .457 .000,00$ & o & 0 & 0 & $473.305 .707 .574,09$ & $477.345,023.639,00$ \\
\hline SILPA Tahun berkenaan & $\overrightarrow{0}$ & d & 0 & 0 & 0 & \\
\hline
\end{tabular}

Sedangkan apabila dilihat dari penerimaan retribusi per tahun ada peningkatan yang masih sedikit. Sebagaimana terlihat pada tabel di bawah ini.

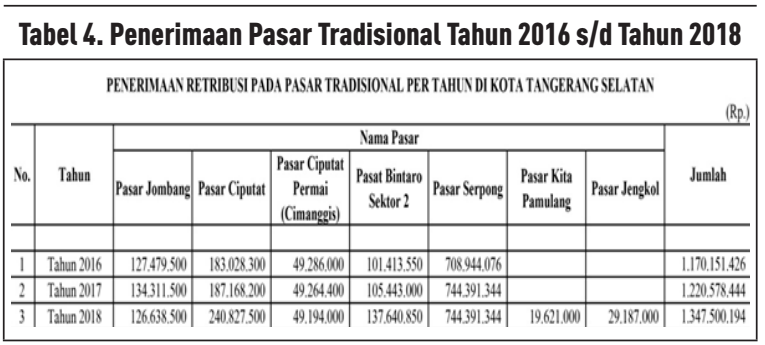

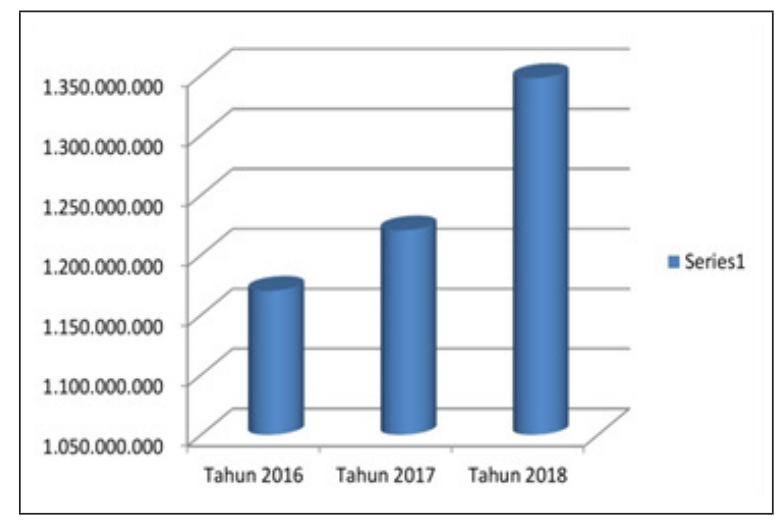

Sumber : Dinas Perindustrian dan Perdagangan Kota Tangerang Selatan, Tahun 2019, Diolah 
Apabila dilihat dari total pendapatan daerah dari pos hasil retribusi daerah, maka dapat dikatakan kontribusi retribusi pasar masih sangat sedikit. Secara berturut-turut tahun 2006 sampai dengan tahun 2018, hasil retribusi daerah pada ABPD Kota Tangerang Selatan yaitu Rp88.916.066.000,-, Rp90.852.771.000,-, , dan Rp.80.729.540.514,--

Sementara itu pendapatan dari hasil retribusi pasar dari tahun 2016 sampai dengan tahun 2018 yaitu berturut-turut sebesar Rp1.170.151.426,, Rp1.220.578.444,-, dan Rp1.347.500.194,-. Dengan demikian kontribusinya dapat dikatakan masih sangat kecil yaitu berkisar antara 1\% sampai 1,5\%.

Kecilnya retribusi pasar tradisional dapat dipahami mengingat lemahnya pengelolaan yang dilakukan selama ini. Hal ini bisa diketahui secara jelas, apabila dibanding dengan pasar modern yang sudah melakukan manajemen secara modern dalam pengelolaannya.

Untuk lebih memberikan gambaran mengenai besaran pendapatan daerah dari hasil retribusi daerah mulai tahun 2014 sampai dengan 2018 san rencana pada tahun 2019, maka dapat dilihat pada tabel detail APBD Kota Tangerang Selatan berikut ini.

Tabel 5. Detail APBD Kota Tangerang Selatan 2014 s/d 2019

\begin{tabular}{|c|c|c|c|c|c|c|}
\hline \multicolumn{7}{|c|}{ APBO KOTA TANGERANG SELATAN DARI TAHUN 2014 S/D TAHUN 2019} \\
\hline Uraian & Tahun 2014 (ruplah) & Tahun 2015 (ruplah) & Talhun 2016 (rupian) & Tahun 2017 (rupiah) & Tahun 2018 (ruplah) & Tahun 2019 (ruplah) \\
\hline \multicolumn{7}{|l|}{ PENDAPATAN } \\
\hline \multicolumn{7}{|l|}{ Prendopoton Asli Doerah } \\
\hline Fasil Pajak Oaerah & 203500.000 .000 .00 & $847.000 .000 .000,00$ & $1002.450000 .000,00$ & 1.120 .086000 .000 .00 & 1.260 .850 .000 .000 .00 & 1.396050 .000 .000 .00 \\
\hline Fasil Reeribusi Oatroh & $74.441 .330000,00$ & $63.323 .330 .000,00$ & $88.916066 .000,00$ & 90.85271 .000 .00 & $80.729 .540514,00$ & $79.768 .000000,00$ \\
\hline $\begin{array}{l}\text { Lain-ain Pendapatan Asli Daerah } \\
\text { pang sah }\end{array}$ & $22.045 .638 .180,00$ & $52.208 .254 .973,00$ & $105.310 .048 .000,00$ & 104.703 .040 .000 .00 & $113.945 .000 .000,00$ & $143.214 .106 .000,00$ \\
\hline Iumlah Pendapatan Asi Daerah & $799.986 .965 .180,00$ & $963.221 .584 .973,00$ & $1.196 .706 .114 .000,00$ & 1.315. $641.811 .000,00$ & 1.455.524.540.514.00 & 1.619.032.106.000,00 \\
\hline \multicolumn{7}{|l|}{ Dang Perimbangan } \\
\hline Dana Bag Hasil Pajake/Bagi Hasil & 105.725 .375 .4870 & & & & & \\
\hline Bukan Pajak & $106.725 .375 .487,00$ & $109.750 .967,000,00$ & $132.404926 .000,000$ & $163.946 .854,000,00$ & $184.291 .149,000,00$ & $228.675 .290 .369,00$ \\
\hline Dana Alokari Umum & $566.429 .457 .000,00$ & $609.519 .143 .000,00$ & $581.505 .815 .000,00$ & 634.150 .767 .702 .00 & $572.637 .313000,00$ & $609.575 .078 .000,00$ \\
\hline Dana Alokasi Khusus & $23,972.450,000,00$ & $25.073 .920 .000,00$ & $226.297 .326 .300,00$ & 149.049507 .000 .00 & $152.702 .482000,00$ & $159.245 .274,000,00$ \\
\hline humblah Dans Perimbangan & 697.127 .312 .487 .00 & $744.344 .030 .000,00$ & 940.208 .067 .300 .00 & 947.147 .128 .702 .00 & $909.630 .944,000,00$ & $997.495 .642 .369,00$ \\
\hline \multicolumn{7}{|l|}{$\begin{array}{l}\text { Lain-Lain Pendapotan Doerah yang } \\
\text { vah }\end{array}$} \\
\hline Pendapatan Hibash & o & c & 하 & 0 & $52.240 .600000,00$ & $90.420 .000 .000,00$ \\
\hline $\begin{array}{l}\text { Dana Ragi Havil Pajak dari Provinai } \\
\text { dan Pemerintah Daerah Lainnya }\end{array}$ & $426.539 .397 .793,00$ & 433.101.896.000,00 & $434.480 .021 .571,00$ & 462.897.133.035.,01 & $518.444 .788 .999,00$ & $550.940 .701 .227,00$ \\
\hline Dana Venvesuaian Otonomi Khusus & $25.270 .927 .000,00$ & $129.531 .038 .000,00$ & 0 & o & $35.000 .000 .000,00$ & $29.155 .470 .000,00$ \\
\hline $\begin{array}{l}\text { amanuan Keuangan dari Prowinsi dan } \\
\text { Pemerintah Daerah Lainnya }\end{array}$ & 0 & $51.443 .901 .125,00$ & 9.065.201.500,00 & $50.000 .000 .000,00$ & $65.000 .000 .000,00$ & \\
\hline $\begin{array}{l}\text { Jumlah Lain-Lain Pendapatan Daerah } \\
\text { yang ahh }\end{array}$ & 451.810.324.793,00 & 614.076.835.125,00 & 443.545.223.071,00 & $512.897 .133 .035,01$ & 710.685.388.999.00 & $670.516 .171 .227,00$ \\
\hline IUMLAH TOTAL MENOAPATAN & 1.948.924.605.460,00 & $2.321 .642 .450 .098,00$ & $2.580 .459 .404 .371, \infty$ & 2.775 .656 .072 .737 .01 & 3.075 .840 .873 .513 .00 & $3.287 .043 .919 .596,00$ \\
\hline \multicolumn{7}{|l|}{ BELANUA DAERAH } \\
\hline \multicolumn{7}{|l|}{ Belanja Fidak Langsung } \\
\hline Belanja Pefawai & $478.112 .051 .665,00$ & $640.991 .173 .3888,57$ & $729.015,399.464,00$ & 646.100 .474 .665 .01 & 847.315 .755 .286 .66 & 917.195 .989 .062 .84 \\
\hline Belanja Hibah & $17.455 .400,000,00$ & $29.568 .000,000,00$ & $67.490,395.000,00$ & 83.949 .800 .000 .00 & 79.148 .700 .000 .00 & $43.061 .530,000,00$ \\
\hline \begin{tabular}{|l} 
Belanjas Bantuan Sosial \\
\end{tabular} & $20,000.000 .000,00$ & $1.944,000,000,00$ & $\Rightarrow$ & 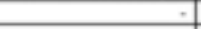 & $2.124 .500,000,00$ & \\
\hline $\begin{array}{l}\text { Belanja Bantuan Kewangan Kepada } \\
\text { Provimi/Kabupaten/Kota. } \\
\text { Pemerimtahan Desa dan Partai Polinik }\end{array}$ & $722.638 .442,00$ & $416.319 .293,00$ & $416.319 .293,00$ & 416.319 .293 .00 & $1.940 .036 .800,00$ & $1.940 .036: 800,00$ \\
\hline Belanja Tidak Terduga & $4.168 .244944,00$ & $9.356 .747940,43$ & $14.491 .447,000,00$ & 1.741 .000 .000 .00 & 4.149 .299 .217 .43 & $5.123 .370 .000,16$ \\
\hline Iumlah Belanga Tidak Langung & 520.458 .335 .051 .00 & $692.276 .240 .622,00$ & $811.413 .560 .757,00$ & 732.207 .593 .958 .02 & 934.678 .291 .304 .09 & $967.320 .925 .863,00$ \\
\hline \multicolumn{7}{|l|}{ Belanja Langiung } \\
\hline Belanja Pegawai & $211.747 .360 .975,00$ & $284.273 .457 .144,00$ & $315.810 .916 .300,00$ & 13.100 .725 .900 .00 & $395.020 .945600,00$ & $40.518 .100 .452,00$ \\
\hline Belanja Barang dan dass & $655595.4345533,00$ & $720.808 .518 .772,00$ & $864.6 \mathrm{k8} .199 .374,00$ & 958.293 .304 .793 .00 & $937.703 .708570,00$ & $1.188 .862 .016 .117,00$ \\
\hline Belanja Modal & 1.053 .772 .951 .981 .00 & 1.156 .529 .829 .48900 & 1.292 .800 .790 .968 .00 & 1.421 .076 .388 .086 .00 & 1.281 .743 .635 .613 .00 & $1.192 .667 .860 \times 03,00$ \\
\hline Iumlah Belanja Lanfwuns. & $1.973 .115 .727 .409,00$ & $2.161 .611 .805 .445,00$ & 2.493 .308 .806 .642 .00 & 2.711 .478 .478 .779 .00 & $2.614 .468 .289 .783,00$ & $2.797 .068 .017 .372,00$ \\
\hline IUMLAH TOTAL BELANZA DAERAH & 2.493 .574 .062 .460 .00 & $2.843 .888 .046 .067,00$ & $3.304 .722 .367 .399,00$ & 3.443 .646 .072 .737 .01 & 3.549 .146 .581 .087 .09 & $3.764 .388 .943 .235,00$ \\
\hline & & & & & & \\
\hline \multicolumn{7}{|l|}{ PEMaLAYMaN } \\
\hline \multicolumn{7}{|l|}{ Permerimoan Pembioroan Daerah } \\
\hline SILPA Tahun Anegaran Sebelumnya & $566.429 .457 .000,00$ & $522.245 .595 .969,00$ & $724.262 .963 .028,00$ & $668.000 .000 .000,00$ & 495.305.707.574,09 & 499.345.023.639,00 \\
\hline \multicolumn{7}{|l|}{ Pregehuran Pembioroan Daeroh } \\
\hline $\begin{array}{l}\text { Pemvertaan Modal/imvestasi } \\
\text { Pemerimtah Daerah }\end{array}$ & $21.780 .000,000,00$ & of & 이 & of & $22.000 .000 .000,00$ & $22.000,000,000,00$ \\
\hline \multirow[t]{3}{*}{ IUMLAH TOTAL NCMBLAYMAN } & $544.649 .457 .000,00$ & $522.245 .595 .969,00$ & $724.262 .963 .023,00$ & 665.000 .000 .000 .00 & 471.305 .707 .574 .09 & $477.345 .023 .639,00$ \\
\hline & & & & & & \\
\hline & 1.248 .924 .605 .460 .00 & $2.321 .642 .450 .028,00$ & $2580.450 .404 .371,00$ & 2.775 .686 .072 .737 .01 & 3.075 .840 .873 .513 .00 & $3.287043 .919 .526,00$ \\
\hline
\end{tabular}


Selanjutnya untuk lebih mengetahui persepsi dari para pengelola pasar terhadap konsep revitalisasi, maka telah dilakukan wawancara kepada para kepala pasar. Selain wawancara yang dilakukan secara personal, maka untuk lebih memberikan penguatan terhadap penelitian ini diadakan pula Focus Group Discussion (FGD) yang dihadiri Kepala UPTD Pengelolaan Pasar Dinas Perindustrian dan Perdagangan Kota Tangerang Selatan, serta dihadiri oleh para kepala pasar tradisional yang ada di Tangerang Selatan dan perwakilan pasar yaitu pada Rabu, 4 September 2019.

Dalam wawancara personal maupun FGD tercermin keinginan dari para pengelola pasar untuk segera melakukan revitalisasi pasar tradisional yang ada di Tangerang Selatan. Karena diyakini dengan adanya revitalisasi pasar, maka akan semakin memperkuat pengelolaan pasar. Berikut tabel persepsi pengelola pasar terhadap konsep revitalisasi.

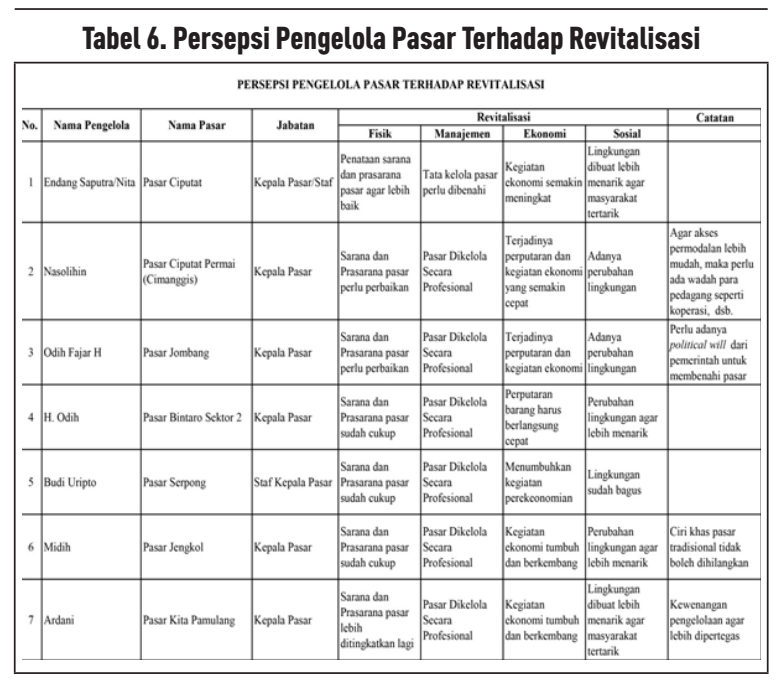

Sumber : Hasil Wawancara, Tahun 2019, Diolah

\section{Pembahasan}

Berdasarkan data yang diperoleh, baik primer maupun sekunder serta hasil observasi dan wawancara kepada sejumlah pihak, maka telah dilakukan analisis di mana apabila dilakukan revitalisasi pasar tradisional, maka akan meningkatkan pendapatan daerah. Dengan adanya revitaliasi pasar, maka akan membuka peluang untuk menarik pos-pos pendapatan baru selain retribusi dari pedagang.

Selanjutnya potensi pendapatan yang akan diperoleh apabila pasar tradisional yang ada di
Kota Tangerang Selatan direvitalisasi sangat besar sekali. Pendapatan tidak hanya berasal dari retribusi, namun juga dari sektor-sektor lain. Hal itu sebagaimana terlihat pada tabel berikut.

\begin{tabular}{|c|c|c|c|c|}
\hline \multicolumn{5}{|c|}{ POTENSI PENDAPATAN PASAR SETELAH REVITALISASI } \\
\hline No. & Nama Pengelola & Nama Pasar & Jabatan & Potensi \\
\hline 1 & Endang Saputra/Nita & Pasar Ciputat & $\begin{array}{l}\text { Kepala } \\
\text { Pasar/Staf }\end{array}$ & $\begin{array}{l}\text { 1. Retribusi, 2. Pengelolaan Parkir, } 3 . \\
\text { Pajakk Restoran, , Reklame , 5. zin } \\
\text { Usaha Pertokoan, 6. PBB }\end{array}$ \\
\hline 2 & Nasolihin & $\begin{array}{l}\text { Pasar Ciputat Permai } \\
\text { (Cimanggis) }\end{array}$ & Kepala Pasar & $\begin{array}{l}\text { 1. Retribusi, 2. Pengelolaan Parkir, } 3 . \\
\text { Pajak Restoran, 4. Reklame, 5. Izin } \\
\text { Usaha Pertokoan }\end{array}$ \\
\hline 3 & Odih Fajar H & Pasar Jombang & Kepala Pasar & $\begin{array}{l}\text { 1. Retribusi, 2. Pengelolaan Parkir, } 3 . \\
\text { Pajak Restoran, 4. Reklame, 5. zzin } \\
\text { Usaha Pertokoan, 6. PBB }\end{array}$ \\
\hline 4 & H. Odih & Pasar Bintaro Scktor 2 & Kepala Pasar & $\begin{array}{l}\text { 1. Retribusi, 2. Pengelolaan Parkir, } 3 . \\
\text { lijin Restoran, 4. Reklame, 5. Izin } \\
\text { Usaha Pertokoan }\end{array}$ \\
\hline 5 & Budi Uripto & Pasar Serpong & $\begin{array}{c}\begin{array}{c}\text { Staf Kepala } \\
\text { Pasar }\end{array} \\
\end{array}$ & $\begin{array}{l}\text { 1. Retribusi, 2. Pengelolaan Parkir, } 3 \\
\text { Pajak Restoran, 4. Reklame, 5. Izin } \\
\text { Usaha Pertokoan }\end{array}$ \\
\hline 6 & Midih & Pasar Jengkol & Kepala Pasar & $\begin{array}{l}\text { 1. Retribusi, 2. Pengelolaan Parkir, } 3 . \\
\text { Pajak Restoran, 4. Reklame, 5. } \\
\text { Pengelolaan Sampah }\end{array}$ \\
\hline 7 & Ardani & Pasar Kita Pamulang & Kepala Pasar & 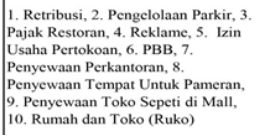 \\
\hline
\end{tabular}

Sumber : Hasil Wawancara, Tahun 2019, Diolah.

Dengan demikian, revitalisasi pasar tradisional yang ada di Kota Tangerang Selatan akan berpengaruh terhadap pendapatan daerah. Apabila revitalisasi dilakukan, maka pendapatan daerah akan meningkat.

Hasil analisis terhadap prinsip revitalisasi pasar tradisional di Kota Tangerang Selatan adalah sebagai berikut :

FISIK. Meliputi perbaikan dan peningkatan kualitas dan kondisi fisik bangunan, tata hijau, sistem penghubung, sistem tanda/reklame dan ruang terbuka kawasan.

Perbaikan fisik akan semakin menarik masyarakat untuk datang ke pasar tradisional. Pasar yang nyaman, bersih, dan bebas polusi akan meningkatkan animo untuk berbelanja. Hal ini berdampak pada pemasukan daerah melalui biaya jasa layanan yang akan dikeluarkan oleh setiap masyarakat yang datang ke pasar tradisional.

MANAJEMEN. Revitalisasi mampu membangun manajemen pengelolaan pasar yang mengatur secara jelas aspek-aspek seperti hak dan kewajiban pedagang, tata cara penempatan dan pembiayaan, fasilitas-fasilitas yang harus tersedia di pasar standar operasional prosedur pengelolaan dan pelayanan pasar.

Apabila manajemen pengelolaan pasar tradisional dilakukan secara profesional, maka akan 
semakin jelas hak dan kewajiban pedagang. Semakin mempermudah pedagang dalam memperoleh permodalan yang murah dan tidak terbebani sehingga pedagang akan semakin memiliki motivasi dan semangat dalam berdagang karena setiap hari ada pendapatan yang mereka peroleh tanpa harus memikirkan besarnya bunga pinjaman modal. Kemudian akan memperjelas SOP pengelolaan pasar di mana pedagang lebih tertib dan tertata dalam mengelola usahanya. Dampaknya bagi pemerintah akan semakin naiknya pendapatan dari retribusi pedagang, apalagi pedagang yang berjualan juga semakin tambah.

EKONOMI. Perbaikan fisik kawasan yang bersifat jangka pendek, untuk mengakomodasi kegiatan ekonomi informal dan formal (local economic development).

Kesempatan untuk berusaha semakin besar baik dalam sektor informal maupun formal. Pelaku pasar akan semain tambah jumlahnya. Sektor perekonomian daerah semakin tinggi perputarannya.

Dampaknya, yaitu akan memicu perekonomian wilayah. Dengan demikian implikasi yang diharapkan adalah meningkatnya pendapatan dari sektor perekonomian yang secara langsung maupun tidak langsung beringgungan dengan proses bisnis yang ada di pasar tradisional.

SOSIAL. Menciptakan lingkungan yang menarik (interesting), dan berdampak positif serta dapat meningkatkan dinamika dan kehidupan sosial masyarakat/warga (public realms).

Perubahan perilaku masyarakat dalam berbelanja dan perilaku pedagang dalam berdagang apabila pasar tradisional di-revitalisasi akan memberikan dampak positif bagi pertumbuhan dan perkembangan pasar tradisional. Namun dari prinsip sosial budaya, ciri khas pasar taradisional atau ciri khas daerah Kota Tangerang Selatan yang dibenamkan ke dalam bangunan fisik pasar tradisional tidak boleh dihilangkan agar menarik masyarakat secara kultural untuk datang berbelanja ke pasar.

Ciri khas pasar tradisional yang senantiasa menyediakan bahan-bahan dagangan yang masih segar atau fresh merupakan daya tarik tersendiri bagi masyarakat. Dampaknya, semakin menarik minta masyarakat berbelanja ke pasar tradisional daripada pasar modern atau mall yang menyediakan bahan-bahan dagangan yang sudah tidak segar dan diawetkan. Semakin banyak masyarakat yang berbelanja ke pasar tradisional, secara ekonomi semakin meningkat pendapatan daerah yang berasal dari retribusi turunan atau retribusi ikutan di luar retrtibusi dari pedagang pasar yang berasal dari iuran bulanan.

Sampai dengan penelitian ini dilaporkan, menurut hemat peneliti belum ada kebijakan secara khusus baik dalam bentuk Perda, Perwal, maupun Kepwal yang dikeluarkan oleh Pemerintah Kota Tangerang Selatan dalam rangka pengelolaan pasar tradisional. Selama ini pengelolaaan pasar tradisional dilaksanakan oleh Dinas Perindustrian dan Perdagangan Kota Tangerang Selatan, khususnya UPTD Pengelolaan Pasar. Kemudian secara teknis di lapangan, pasar tradisional tersebut di-manage secara langsung oleh para kepala pasar.

Begitu pula dengan kebijakan revitalisasi pasar tradisional, di mana Pemerintah Kota Tangerang Selatan baru sebatas wacana. Sejak aset pasar diserahkan dari Pemerintah Kabupatan Tangerang ke Pemerintah Kota Tangerang Selatan sudah diwacanakan bahwa pasar-pasar tradisional yang diserahkan tersebut akan segera direvitalisasi.

Bahkan, belakangan diwacanakan pula bahwa pasar tradisional akan dikelola oleh PT Pembangunan Investasi Tangerang Selatan, yaitu sebuah Badan Usaha Milik Daerah (BUMD) yang sudah ditetapkan melalui Perda Nomor 2 Tahun 2013 tentang Pembentukan Badan Usaha Milik Daerah.

Wakil Wali Kota Tangerang Selatan Benyamin Davnie pernah mengatakan bahwa Pemerintah Kota Tangerang Selatan berencana menyerahkan pengelolaan sejumlah pasar tradisional kepada BUMD Tangsel. Hal ini dimaksudkan agar bisa dikelola secara lebih profesional. Sebab, selama ini pengelolaan Pasar Ciputat, Jombang, dan Bintaro, tidak pernah menguntungkan. Sehingga pengelolaan pasar harus berorientasi keuntungan. Sedang Pemkot Tangsel sendiri akan fokus kepada pelayanan publik. Oleh karena itu, 
maka pengelolaan pasar lebih tepat ditangani oleh BUMD, karena harus berorientasi pada keuntungan atau profit oriented.

\section{SIMPULAN}

Berdasarkan hasil penelitian menunjukkan bahwa revitalisasi pasar tradisional di Kota Tangerang Selatan mutlak dilakukan. Dengan adanya revitalisasi pasar akan mendorong pengelolaan pasar yang lebih modern. Adapun konsep revitalisasi meliputi fisik, manajemen, ekonomi, dan sosial.

Data menunjukkan bahwa pendapatan dari retribusi pasar tradisional di Kota Tangerang Selatan dari tahun 2016 s/d tahun 2018 yaitu berturut-turut sebesar Rp1.170.151.426, Rp1.220.578.444,-, dan Rp1.347.500.194,-. Dengan demikian kontribusinya dapat dikatakan masih sangat kecil yaitu berkisar antara $1 \%$ sampai $1,5 \%$, apabila dibandingkan dengan perolehan retribusi secara keseluruhan yang ada pada APBD Kota Tangerang Selatan.

Setelah dilakukan revitaliasi, adapun potensi pendapatan selain dari retribusi, yaitu antara lain dari pengelolaan parkir, pajak restoran, reklame, izin usaha pertokoan, pajak bumi dan bangunan, penyewaan perkantoran, penyewaan tempat untuk pameran, penyewaan toko seperti di mall, rumah dan toko (ruko), dan pengelolaan sampah.

Implikasi dari hasil penelitian ini adalah segera dilakukannya revitalisasi pasar tradisional oleh Pemerintah Kota Tangerang Selatan. Sedangkan pengembangan hasil temuan yaitu akan dilakukannya penelitian lebih lanjut setelah pasarpasar tradisional direvitalisasi.

Pemerintah Kota Tangerang Selatan perlu segera mengambil kebijakan dalam bentuk regulasi apakah melalui Perda, Perwal, maupun Kepwal untuk memperkuat kebearadaan pasar tradisional.

Pemerintah Kota Tangerang Selatan harus berhati-hati dalam menunjuk para pengelola pasar tradisional, sehingga kelak tidak menjadi beban bagi pemerintah, baik dari segi manajemen maupun keuangan.

\section{PENGHARGAAN}

Penelitian ini dibiayai sepenuhnya oleh Direktorat Riset dan Pengabdian Masyarakat Direktorat Jenderal Penguatan Riset dan Pengembangan Kementerian Riset, Teknologi, dan Pendidikan Tinggi Tahun Anggaran 2019. Untuk itu saya mengucapkan terimakasih yang telah memberikan kepercayaan melaksanakan penelitian. Ucapan terima kasih disampaikan pula kepada Dinas Perindustrian dan Perdagangan Kota Tangerang Selatan, khususnya UPTD Pengelolaan Pasar. Selain itu ucapan terima kasih juga disampaikan kepada para Kepala Pasar Tradisional dan Kepala Pasar Modern yang ada di Kota Tangerang Selatan.

\section{DAFTAR PUSTAKA}

Bintoro, R.W., (2010, September). Aspek Hukum Zonasi Pasar Tradisional dan Pasar Modern, Jurnal Dinamika Hukum, Vol. 10, No. 3: 360374.

Firdaus, Ahmad Heri, (2019). https://www. pikiran-rakyat.com/ekonomi/2019/03/12/ bangkitkan-ekonomi-kerakyatanrevitalisasi-pasar-tradisional-mestidigalakkan.

Halim, Abdul, (2002). Akuntansi Sektor Publik Akuntansi Keuangan Daerah.

Halim, Abdul, (2002). Akuntansi Keuangan Daerah.

H. Lukman, (2006). Badan Pendidikan dan Pelatihan Daerah.

Handoko, A.T., (2012). Analisis Perkembangan Retribusi Pasar Daerah sebagai Sumber Pembiayaan Otonomi Daerah di Kab. Pemalang Tahun 2007-2011, Economics Development Analysis Journal, 1 (2): 1-7.

Istiningtyas, D.A., (2018, January 7). Analisis Kebijakan dan Strategi Pengembangan Pasar Tradisional di Kota Bogor, Skripsi, Institut Pertanian Bogor, http://repository.ipb.ac.id/ handle/123456789/1509.

Marselina, E., (2013). Analisis Kontribusi Pajak Parkir dan Retribusi Pasar terhadap Pendapatan Asli Daerah pada Pemerintah Kota Padang, Jurnal Akuntansi, Vol. 1, No. 1: 
$1-25$.

Martini, L.K.B., Kepramareni, P., Widyani, A.A.D., (2016, August 29-30). Strategi Pengembangan Pasar Tradisional dalam Upaya Mengantisipasi Pertumbuhan Pasar Modern di Bali, Seminar Nasional Hasil Penelitian dan Pengabdian Kepada Masyarakat, "Inovasi Iptek Perguruan Tinggi untuk Meningkatkan Kesejahteraan Masyarakat, Unmas Denpasar. Megawati, N.A., \& Soejoto, A., (2016). Kontribusi Retribusi Pasar terhadap Pendapatan Asli Daerah (PAD) Kabupaten Sidoarjo, Jurnal Pendidikan Ekonomi, Vol. 4, No. 3: 1-10.

Noor, A., (2013, November). Perlindungan terhadap Pasar Tradisional di Tengah Ekspansi Pasar Ritel Modern, Economica, Vol. IV, Edisi 12: 107-120.

Pratisto, Arief., (2004). Cara mudah mengatasi masalah Statistik dan Rancangan Percobaan dengan SPSS 12. PT Elex Media Komputindo, Jakarta.

Purwanto, W., (2012, October). Analisa Persaingan Antara Pasar Tradisional dengan Pasar Modern Studi Kasus di Kawasan Ciledug Tangerang, Jurnal MIX, Vol. 5, No. 3: 113-124.

Sadino \& Syahbana, J.A., (2014, June). Pasar Tradisional Versus Pasar Modern di Daerah Perkotaan (Studi Kasus: Kecamatan [2] Gondokusuman Kota Yogyakarta), Jurnal Pembangunan Wilayah dan Kota, Vol. 10 (2): 205-217.

Sugiyono, (2012). Metode Penelitian Kuantitatif, Kualitatif dan R\&D. Bandung: Alfabeta.

Sukaatmadja, I.P.G., Yasa, N.N.K., Rahyuda, H., Widagda, I.G.A.Ngr.J., (2014, August). Strategi Pengembangan Pasar Tradisional Berbasis Kearifan Lokal untuk Mengentaskan Kemiskinan di Bali, Jurnal Manajemen, Strategi Bisnis dan Kewirausahaan, Vol. 8, No. 2: 121-129.

Suparmoko, (2001). M., Ekonomi Publik.

Suryadarma, D., Poesoro, A., Akhmadi, Budiyati, S., Rosfadhila, M., Surhayadi, A., (2010). Traditional Food Traders in Developing Countries and Competition from Supermarket: Evidence from Indonesia, Food Policy, 35: 79 -
86.

Suryadarma, D., Poesoro, A., Budiyati, S., Akhmadi, Rosfadhila, M., (2018, January 7). Dampak Supermarket terhadap Pasar dan Pedagang Ritel Tradisional di Daerah Perkotaan di Indonesia, SMERU Research Institute, http://www.smeru.or.id/sites/ default/files/publication/supermarket_ind. pdf.

Yandri, Pitri, (2018, September). Determinasi Tarif Retribusi Pasar Tradisional Dengan Pendekatan Willingness To Pay dan Perbandingan Harga Pasar, AGREGAT: Jurnal Ekonomi dan Bisnis, Vol. 2, No. 2: 306-323.

Zain, Mohammad, (2003). Manajemen Perpajakan.

https://metro.sindonews.com/read/1428972/171/ pemkot-tangsel-serahkan-pengelolaanpasar-tradisional-ke-bumd-1565572057 